\title{
Strategies for reducing the carbon footprint of field crops for semiarid areas. A review
}

\author{
Yantai Gan • Chang Liang • Chantal Hamel • \\ Herb Cutforth $\cdot$ Hong Wang
}

Accepted: 23 November 2010 / Published online: 8 March 2011

(C) INRA and Springer Science+Business Media B.V. 2011

\begin{abstract}
The Earth's climate is rapidly changing largely due to increasing anthropogenic greenhouse gas (GHG) emissions. Agricultural practices during crop production, food processing, and product marketing all generate GHG, contributing to the global climate change. The general public and farmers are urging the development and adoption of effective measures to reduce GHG emissions from all agricultural activities and sectors. However, quantitative information is not available in regard to what strategies and practices should be adopted to reduce emission from agriculture and how crop productivity would affect the intensity of GHG emission. To provide the potential solution, we estimated the carbon footprint [i.e., the total amount of GHG associated with the production and distribution of a given food product expressed in carbon dioxide equivalence $\left(\mathrm{CO}_{2} \mathrm{e}\right)$ ] for some of the major field crops grown on the Canadian prairie and assessed the effect of crop sequences on the carbon footprint of durum wheat. Key strategies for reducing the carbon footprint of various field crops grown in semiarid areas were identified. Carbon footprints were estimated using emissions from (1) the decomposition of crop straw and roots; (2) the manufacture of $\mathrm{N}$ and $\mathrm{P}$ fertilizers and their rates of application; (3) the production of herbicides and fungicides;
\end{abstract}

Y. Gan $(\varangle) \cdot$ C. Hamel $\cdot$ H. Cutforth $\cdot$ H. Wang Semiarid Prairie Agricultural Research Centre, Agriculture and Agri-Food Canada, Swift Current, SK S9H 3X2, Canada

e-mail: yantai.gan@agr.gc.ca

C. Liang

Greenhouse Gas Emission Division, Environment Canada, 9th Floor, Fontain Building, 200 Sacré-Coeur,

Gatineau, QC K1A 0H3, Canada and (4) miscellaneous farm field operations. Production and application of $\mathrm{N}$ fertilizers accounted for $57 \%$ to $65 \%$ of the total footprint, those from crop residue decomposition $16 \%$ to $30 \%$, and the remaining portion of the footprint included $\mathrm{CO}_{2} \mathrm{e}$ from the production of $\mathrm{P}$ fertilizer and pesticides, and from miscellaneous field operations. Crops grown in the Brown soil zone had the lowest carbon footprint, averaging $0.46 \mathrm{~kg} \mathrm{CO}_{2} \mathrm{e} \mathrm{kg}^{-1}$ of grain, whereas crops grown in the Black soil zone had a larger average carbon footprint of $0.83 \mathrm{~kg} \mathrm{CO}_{2} \mathrm{e} \mathrm{kg}^{-1}$ of grain. The average carbon footprint for crops grown in the Dark Brown soil zone was intermediate to the other two at $0.61 \mathrm{~kg} \mathrm{CO}_{2} \mathrm{e} \mathrm{kg}^{-1}$ of grain. One kilogram of grain product emitted $0.80 \mathrm{~kg} \mathrm{CO}_{2} \mathrm{e}$ for canola (Brassica napus L.), 0.59 for mustard (Brassica juncea L.) and flaxseed (Linum usitatissimum L.), 0.46 for spring wheat (Triticum aestivum L.), and 0.20 to $0.33 \mathrm{~kg}$ $\mathrm{CO}_{2} \mathrm{e}$ for chickpea (Cicer arietinum L.), dry pea (Pisum sativum L.), and lentil (Lens culinaris Medik.). Durum wheat (T. aestivum L.) preceded by an $\mathrm{N}$-fixing crop (i.e., pulses) emitted total greenhouse gases of $673 \mathrm{~kg} \mathrm{CO}_{2} \mathrm{e}$, $20 \%$ lower than when the crop was preceded by a cereal crop. Similarly, durum wheat preceded by an oilseed emitted $744 \mathrm{~kg} \mathrm{CO} \mathrm{CO}_{2} \mathrm{e}, 11 \%$ lower than when preceded by a cereal. The carbon footprint for durum grown after a pulse was $0.25 \mathrm{~kg} \mathrm{CO}_{2} \mathrm{e}$ per $\mathrm{kg}$ of the grain and $0.28 \mathrm{~kg} \mathrm{CO}_{2} \mathrm{e}$ per $\mathrm{kg}$ of the grain when grown after an oilseed: a reduction in the carbon footprint of $24 \%$ to $32 \%$ than when grown after a cereal. The average carbon footprint can be lowered by as much as $24 \%$ for crops grown in the Black, $28 \%$ in the Dark Brown, and $37 \%$ in the Brown soil zones, through improved agronomic practices, increased $\mathrm{N}$ use efficiency, use of diversified cropping systems, adoption of crop cultivars with high harvest index, and the use of soil bioresources such as P-solublizers and arbuscular mycorrhizal fungi in crop production. 
Keywords Carbon footprint - Legumes · Oilseeds . Broadleaf crops · Biochar · Crop diversification · Carbon sequestration $\cdot$ Straw management $\cdot$ Input $\cdot \mathrm{N}$-fixation

\section{Contents}

1. Introduction . . . . . . . . . . . . . . . 2

2. Calculation of carbon footprints ........... 3

3. Strategies and practices for lowering carbon footprints . 3

3.1. Choosing crop species with a low carbon footprint . . 3

3.2. Diversifying cropping systems to reduce carbon

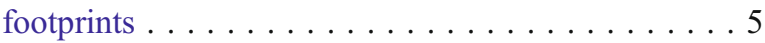

3.3. Including biological $\mathrm{N}$-fixation to reduce the input of synthetic $\mathrm{N}$ fertilizer. . . . . . . . . . . . 7

3.4. Improving nutrient use efficiency using biotechnologies valorizing soil microbial resources . . . . . . . 8

3.5. Cropping systems and energy use efficiency in the semiarid Canadian prairie . . . . . . . . . . 10

3.6. Improving crop residue management in farming systems . . . . . . . . . . . . . . . 11

4. Conclusions .................. 12

5. References .................... . 12

\section{Introduction}

Scientific evidence suggests the Earth's climate has recently been rapidly changing, largely due to increasing anthropogenic greenhouse gas (GHG) emissions (Ruddiman 2003; IPCC 2006). Policy-makers, the general public, and farmers are concerned about climate change and are urging the development and adoption of effective measures to reduce GHG emissions from all sectors. Ambitious actions leading to drastic reduction of GHG emissions may initially be detrimental to the growth of the economy (Wiedmann et al. 2006), but this initial cost will likely be small compared with the damage caused by climate change several decades hence (Viscusi and Zeckhauser 2006).

Agriculture includes the production of various grains, fibers, feedstocks, and fresh produce such as vegetables and fruits, as well as marketing these products along food chains. Crop production, food processing, and product marketing all generate GHG, contributing to global climate change (Dyer et al. 2010). In 2008, agriculture in Canada produced approximately 62 million tonnes of $\mathrm{CO}_{2}$ equivalent emissions, about $8 \%$ of Canada's total emissions (Environment Canada 2010). Nearly two thirds of agricultural emissions occur as $\mathrm{N}_{2} \mathrm{O}$, which has 300 times the global warming potential of $\mathrm{CO}_{2}$ (Forster et al. 2007). Emissions in agriculture also include those from the inputs of fertilizers, manures, plant litter, and those from the interwoven flows of $\mathrm{N}$ among several pools. Farming also removes $\mathrm{CH}_{4}$ from the ecosystem by the oxidative activity of soil microbes, but such removals are small compared with emissions (Janzen et al. 2006).

"Carbon footprint" has become a widely used term in the public debate on the abatement action required to diminish the threat of global climate change (Wiedmann and Minx 2008). The term originally stemmed from the first academic publication discussing "ecological footprinting" by Rees (1992) and was further defined by Wackernagel (1994) who provided a more detailed method of calculating footprints. In general, carbon footprint stands for a certain amount of gaseous emissions that are relevant to climate change and associated with human production or consumption activities. Wiedmann and Minx (2008) discussed in detail the definition of carbon footprint and defined carbon footprint as "a measure of the exclusive total amount of carbon dioxide emissions that is directly and indirectly caused by an activity or is accumulated over the life stages of a product". However, this definition does not emphasize emissions of greenhouse gases other than $\mathrm{CO}_{2}$. With regards to crop production and other agricultural services, a larger portion of the total GHG emission occurs as $\mathrm{N}_{2} \mathrm{O}$, rather than $\mathrm{CO}_{2}$ (Janzen et al. 2006). Therefore, in our discussion, the carbon footprint relevant to agricultural products and processes is defined as the total amount of greenhouse gas emission associated with a food product or a service, expressed in carbon dioxide equivalence $\left(\mathrm{CO}_{2} \mathrm{e}\right)$. The focus is on two components: (1) the total emission per unit area per year expressed as kilograms $\mathrm{CO}_{2} \mathrm{e}$ per hectare per year, and (2) the emission per unit (kilograms) of product produced expressed as kilograms $\mathrm{CO}_{2} \mathrm{e}$ per kilogram of product. These two components parallel the approaches with which the efficiency of agricultural productivity is evaluated, i.e., (1) the net production per unit area such as grain yield per hectare per year and (2) the costs associated with the production of a unit of product such as input costs per kilograms of grain produced.

Most consumers and citizens are willing to pay for measures leading to drastic reductions in GHG emissions. A growing number of consumers want to know the carbon footprint of the food products they buy in grocery stores. In response, some multinational food companies have proposed that suppliers identify on product labels the $\mathrm{CO}_{2} \mathrm{e}$ emissions released in the production of that particular food item. Farmers are eager to adopt improved mitigation practices on their farms. Therefore, it is critical that integrated strategies and practices are developed for farming systems so as to maximize agriculture's productivity while minimizing the greenhouse gas emissions in the production of grains, fibers, feedstocks, and other agricultural products. In this paper, we determined the carbon footprint of seven major field crops grown on the Canadian prairie and assessed the effect of cropping systems on the carbon footprint of a major grain crop- 
durum wheat. We also used some examples from the Canadian prairies and summarized key agronomic strategies for reducing the carbon footprint of field crops grown in semiarid environments.

\section{Calculation of carbon footprints}

We estimated the carbon footprint of various products using the sum of the greenhouse gas emissions from (a) the decomposition of straw and roots, (b) the application of synthetic $\mathrm{N}$ fertilizers, (c) the manufacture of $\mathrm{N}$ and $\mathrm{P}$ fertilizers, (d) the production of herbicides and fungicides, and (e) various farm field operations including pre-seeding tillage, sowing, spraying pesticides, harvesting grain products, and storage of grains on-farm when needed. Other emissions such as those associated with labor and machinery depreciation were assumed to be similar between crop species or cropping systems and thus, unless stated otherwise, omitted in the comparisons of various cropping systems.

When a field crop is harvested, a portion of the crop is left on the soil surface to decompose. The remaining plant matter such as straw and roots is a nitrogen $(\mathrm{N})$ source for nitrification and denitrification, contributing directly and indirectly to $\mathrm{N}_{2} \mathrm{O}$ production (Forster et al. 2007). Similarly, the application of synthetic $\mathrm{N}$ fertilizers for crop production generates $\mathrm{N}_{2} \mathrm{O}$. The amount of $\mathrm{N}$ contained in the straw and roots from various crops were estimated using specific crop N concentrations (Janzen et al. 2003), along with crop yields (Gan et al. 2009). The total emissions from crop components were estimated using the Intergovernmental Panel on Climate Change (IPCC) methodology (IPCC 2006) adapted for Canadian conditions (Rochette et al. 2008). Emissions from crop residue decomposition included direct and leaching emissions. Emissions from synthetic $\mathrm{N}$ application included direct, volatilization, and leaching emissions. Direct emission factors for crop residue decomposition and synthetic $\mathrm{N}$ application were determined using the approach of Rochette et al. (2008) as follows:

$\mathrm{EF}=0.022 \mathrm{P} / \mathrm{PE}-0.0048$

where $\mathrm{EF}$ is the emission factor with a unit of kilograms $\mathrm{N}_{2} \mathrm{O}-\mathrm{N}$ per kilogram N; $\mathrm{P} / \mathrm{PE}$ is the ratio of precipitation to potential evapotranspiration during the growing season (May 1-October 31) based on long-term (1950-2008) data. Similarly, the fraction of $\mathrm{N}$ subject to leaching $\left(\mathrm{FRAC}_{\text {leach }}\right)$ is estimated to be proportional to $\mathrm{P} / \mathrm{PE}$ (Rochette et al. 2008) as follows:

FRAC $_{\text {Leach }}=0.3247 \mathrm{P} / \mathrm{PE}-0.0247$

For synthetic $\mathrm{N}$ fertilizer applied in crop production, a portion of $\mathrm{N}$ is volatilized and emitted to the atmosphere.
The IPCC default volatilization factor of $\mathrm{NH}_{3}$ and $\mathrm{NO}_{\mathrm{x}}$ $\left(\mathrm{FRAC}_{\mathrm{GASM}}=0.1\right)$ was used, and the emission factors associated with leaching and volatilization of $\mathrm{N}$ were taken from the 2006 IPCC guidelines (IPCC 2006). The climatic conditions and emission factors for different soil-climatic zones of western Canada are listed in Table 1. Emissions from the production, transportation, storage, and transfer of $\mathrm{N}$ and $\mathrm{P}$ fertilizers to farm fields were estimated using the method of Lal (2004); the average emission factor was $4.8 \mathrm{~kg} \mathrm{CO}_{2} \mathrm{e} \mathrm{kg}^{-1} \mathrm{~N}$ and $0.73 \mathrm{~kg} \mathrm{CO}_{2} \mathrm{e} \mathrm{kg}^{-1} \mathrm{P}_{2} \mathrm{O}_{5}$.

Herbicides and fungicides such as boscalid, bromoxynil, glyphosate, imazamox, imazethapyr, pyraclostrobin, and sethoxydim, are routinely used in the production of field crops on the Canadian prairies. Emission factors for each of these individual pesticides are not available, but we assume that the emission during the processes of production, transportation, storage, and field application are similar between products. Thus, an average emission factor of $23.1 \mathrm{~kg} \mathrm{CO} \mathrm{e} \mathrm{ha}^{-1}$ was used for herbicides and $14.3 \mathrm{~kg}$ $\mathrm{CO}_{2} \mathrm{e} \mathrm{ha}{ }^{-1}$ for fungicides; the estimates were based on the active ingredient of the product (Lal 2004). The absolute value of the carbon footprint for individual products calculated using these factors may vary since the production of each product may differ widely. However, the relative values of the carbon footprint estimated for various crop species (Table 2), and the general trends among cropping systems (Table 3 ) will be reasonable given that the portion of the footprint from pesticides used in agriculture is generally small (Lal 2004).

The emissions associated with miscellaneous farm operations such as no-till planting, pesticide spraying, windrowing (in case of canola), and combine harvesting were estimated using a factor of $14 \mathrm{~kg} \mathrm{CO}_{2} \mathrm{e} \mathrm{ha}^{-1}$ for no-till planting, $5 \mathrm{~kg} \mathrm{CO} \mathrm{CO}_{2} \mathrm{ha}^{-1}$ for herbicide and fungicide application, $18 \mathrm{~kg} \mathrm{CO}_{2} \mathrm{e} \mathrm{ha}{ }^{-1}$ for windrowing, and $37 \mathrm{~kg}$ $\mathrm{CO}_{2} \mathrm{e} \mathrm{ha}{ }^{-1}$ for harvesting (adapted from Lal 2004).

\section{Strategies and practices for lowering carbon footprints}

\subsection{Choosing crop species with a low carbon footprint}

The carbon footprint of a grain product varies with crop species, agronomic practices, and climatic conditions under which the crop is grown. About 32 million ha of farmland are under annual crop production on the Canadian prairies (Campbell et al. 2002), accounting for $>80 \%$ of the annual crop land in Canada. There are three major soil zones on the prairies: the Brown (Aridic Haploboroll), Dark Brown (Typic Boroll), and Black (Typic Haplustoll) Chernozems. Climatic conditions, and thus crops grown, fertilizer and chemical inputs, and field operations vary substantially 
Table 1 Climatic conditions and emission factors for the Brown, Dark Brown, and Black soil zones of the Canadian prairies

\begin{tabular}{|c|c|c|c|}
\hline \multirow[t]{2}{*}{ Climatic conditions and emission factors } & \multicolumn{3}{|l|}{ Soil zones } \\
\hline & Brown & Dark Brown & Black \\
\hline Long-term growing season ${ }^{\mathrm{a}}$ precipitation $(\mathrm{P}), \mathrm{mm}$ & 203 & 288 & 309 \\
\hline Long-term growing season potential evapotranspiration $(\mathrm{PE}), \mathrm{mm}$ & 503 & 495 & 394 \\
\hline $\mathrm{P} / \mathrm{PE}$ & 0.40 & 0.58 & 0.78 \\
\hline Emission factor (EF), $\mathrm{kg} \mathrm{N}_{2} \mathrm{O}-\mathrm{N} \mathrm{kg}^{-1} \mathrm{~N}$ & 0.004 & 0.008 & 0.0125 \\
\hline Leaching factor of $\mathrm{N}$ (FRAC $\left.\mathrm{FEACH}_{\mathrm{L}}\right), \%$ & 10.6 & 16.4 & 0.23 \\
\hline Volatilization of $\mathrm{NH}_{3}$ and $\mathrm{NO}_{\mathrm{x}}\left(\mathrm{FRAC}_{\mathrm{GASM}}\right), \%$ & 0.1 & 0.1 & 0.1 \\
\hline Leaching emission factor (EFLEACH), $\mathrm{kg} \mathrm{N}_{2} \mathrm{O}-\mathrm{N} \mathrm{kg}^{-1}$ & 0.0075 & 0.0075 & 0.0075 \\
\hline Volatilization emission factor $\left(\mathrm{EF}_{\text {VOLAT }}\right), \mathrm{kg} \mathrm{N}_{2} \mathrm{O}-\mathrm{N} \mathrm{kg}{ }^{-1} \mathrm{~N}$ & 0.01 & 0.01 & 0.01 \\
\hline
\end{tabular}

${ }^{a}$ May 1-August 31, 1940-2004

$P E$ is potential evapotranspiration

among the soil zones. The estimates of the carbon footprint for various crops are dependent upon the prevailing climate, and therefore, soil zone.

Calculated using the models described above, the average emissions were 484, 717, and 1,024 $\mathrm{kg} \mathrm{CO}_{2} \mathrm{e}$ $\mathrm{ha}^{-1}$ for field crops grown in the Brown, Dark Brown, and Black soil zones, respectively (Table 2). Major contributors to the emissions are production, transportation, storage and transfer, application of synthetic $\mathrm{N}$ fertilizers, and crop residue decomposition (data not shown). Production and application of $\mathrm{N}$ fertilizers account for about $57 \%$ to $65 \%$ of the total emissions, and crop residue decomposition accounts for a further 16 to $30 \%$, with the percentages increasing with soil zone: Brown $<$ Dark Brown $<$ Black soil zone. The higher emissions associated with crop residue decomposition for the Black soil zone are mainly due to greater crop yield and to a higher emission factor because of more favorable climatic conditions during the growing season (Table 1). The remaining $13 \%$ to $18 \%$ of the emission total are associated with the production of phosphorus fertilizers, herbicides, fungicides, and inoculants (for pulse crops), as well as miscellaneous field operations.

Nitrous oxide is mostly produced during denitrification, which is greatly influenced by soil moisture (Flynn et al. 2005). In moisture-limited conditions, $\mathrm{N}_{2} \mathrm{O}$ emissions increase with increased rainfall (Dobbie et al. 1999; Flynn et al. 2005). The soil $\mathrm{N}_{2} \mathrm{O}$ emissions due to crop residue decomposition and application of synthetic $\mathrm{N}$ fertilizers are estimated as $0.004,0.008$, and $0.0125 \mathrm{~kg} \mathrm{~N}_{2} \mathrm{O}-\mathrm{N} \mathrm{kg}^{-1} \mathrm{~N}$ for the Brown, Dark Brown, and Black soil zones, respectivelylargely because of differences in precipitation and potential evapotranspiration (Table 1).

Among the various crop species evaluated, canola had the largest emission, averaging $1105 \mathrm{~kg} \mathrm{CO}_{2} \mathrm{e} \mathrm{ha}{ }^{-1}$ across

Table 2 Average annual total emissions and estimated carbon footprints of various field crops grown in the Brown, Dark Brown, and Black soil zones of the Canadian prairie

\begin{tabular}{|c|c|c|c|c|c|c|}
\hline \multirow[t]{2}{*}{ Crop } & \multicolumn{3}{|c|}{ Total emission, $\mathrm{kg} \mathrm{CO}_{2} \mathrm{e} \mathrm{ha}^{-1}$} & \multicolumn{3}{|c|}{ Carbon footprint, $\mathrm{kg} \mathrm{CO}_{2} \mathrm{e} \mathrm{kg}^{-1}$ of product } \\
\hline & Brown & Dark Brown & Black & Brown & Dark Brown & Black \\
\hline Canola & $884^{\mathrm{a}}$ & 1,326 & 1,606 & 0.691 & 0.913 & 0.979 \\
\hline Mustard & 496 & 515 & 480 & 0.601 & 0.652 & 1.56 \\
\hline Flaxseed & 446 & 826 & 829 & 0.456 & 0.658 & 0.727 \\
\hline Chickpea & 283 & 362 & $\mathrm{NA}^{\mathrm{b}}$ & 0.254 & 0.406 & N/A \\
\hline Dry pea & 352 & 602 & 711 & 0.189 & 0.287 & 0.335 \\
\hline Lentil & 189 & 245 & $\mathrm{NA}^{\mathrm{b}}$ & 0.164 & 0.237 & N/A \\
\hline Spr. wheat & 741 & 1,145 & 1,493 & 0.383 & 0.533 & 0.56 \\
\hline Means & 484 & 717 & 1,024 & 0.391 & 0.526 & 0.832 \\
\hline
\end{tabular}

${ }^{a}$ Total emissions for a given crop were calculated to include greenhouse gas emissions from (1) the decomposition of straw and roots, (2) the application of synthetic $\mathrm{N}$ fertilizers, (3) the manufacture of $\mathrm{N}$ and $\mathrm{P}$ fertilizers, (4) the production of herbicides and fungicides, and (5) miscellaneous farm field operations such as tillage, planting of the crops, spraying of pesticides, and harvesting of the grain products, and crop productivity (the dry weight of grain, straw, and roots) were obtained from Gan et al. (2009)

$\mathrm{b}$ This crop is not produced in this soil zone 
Table 3 Crop yield, total emission, and estimated carbon footprints of durum wheat grown in diverse cropping systems where durum wheat was preceded by various oilseeds and pulse crops in the previous 2 years

\begin{tabular}{|c|c|c|c|c|c|c|c|}
\hline \multirow{3}{*}{$\begin{array}{l}\text { Crops in previous } \\
2 \text { years before } \\
\text { durum wheat }\end{array}$} & \multirow{3}{*}{$\begin{array}{l}\text { Durum grain yield, } \\
\mathrm{kg} \mathrm{ha}^{-1}\end{array}$} & \multicolumn{4}{|c|}{ Sources of emission, $\mathrm{kg} \mathrm{CO}_{2} \mathrm{e} \mathrm{ha}^{-1}$} & \multirow{3}{*}{$\begin{array}{l}\text { Total } \\
\text { emission }\end{array}$} & \multirow{3}{*}{$\begin{array}{l}\text { Carbon footprint, } \\
\mathrm{kg} \mathrm{CO}_{2} \mathrm{e} \mathrm{kg}^{-1} \text { product }\end{array}$} \\
\hline & & \multicolumn{2}{|c|}{$\begin{array}{l}\text { Crop } \\
\text { productivity }\end{array}$} & \multicolumn{2}{|l|}{ Input } & & \\
\hline & & Straw & Roots & Nutrient/pesti. ${ }^{\mathrm{b}}$ & Farm operat. ${ }^{c}$ & & \\
\hline Cereal-cereal $^{\mathrm{a}}$ & 2,240 & 122 & 50 & 404 & 257 & 833 & 0.372 \\
\hline Cereal-oilseed & 2,510 & 136 & 59 & 392 & 251 & 838 & 0.334 \\
\hline Cereal-pulse & 2,500 & 100 & 46 & 361 & 232 & 739 & 0.296 \\
\hline Oilseed-cereal & 2,560 & 94 & 41 & 398 & 255 & 788 & 0.308 \\
\hline Oilseed-oilseed & 2,540 & 94 & 41 & 355 & 229 & 719 & 0.283 \\
\hline Oilseed-pulse & 2,620 & 97 & 47 & 332 & 215 & 691 & 0.264 \\
\hline Pulse-cereal & 2,560 & 116 & 51 & 355 & 228 & 750 & 0.293 \\
\hline Pulse-oilseed & 2,630 & 117 & 54 & 356 & 229 & 756 & 0.287 \\
\hline Pulse-pulse & 2,660 & 126 & 59 & 276 & 181 & 642 & 0.241 \\
\hline
\end{tabular}

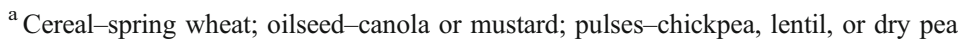

${ }^{\mathrm{b}}$ Includes N, P, seed, herbicides, and fungicides

${ }^{\mathrm{c}}$ Includes no-till planting, herbicide and fungicide spraying, windrowing, and combine harvesting

the Canadian semiarid prairie represented by the Brown and Dark Brown soil zones, followed by spring wheat at $943 \mathrm{~kg}$ $\mathrm{CO}_{2} \mathrm{e} \mathrm{ha}{ }^{-1}$ and then by flaxseed at $636 \mathrm{~kg} \mathrm{CO}_{2} \mathrm{e} \mathrm{ha}{ }^{-1}$ (Table 2). The three $\mathrm{N}$-fixing crops (i.e., pulse crops: chickpea, lentil, and dry pea) had an average emission of $339 \mathrm{~kg} \mathrm{CO}_{2} \mathrm{e} \mathrm{ha}^{-1}, 65 \%$ lower than the emissions of canola and spring wheat. Overall, the total emission by a crop is highly associated with the quantity of $\mathrm{N}$ fertilizer applied, modified by the crop yield and the $\mathrm{N}$ concentrations in the various crop components such as straw and roots.

The estimate of carbon footprint is based on the emissions released in the production of $1 \mathrm{~kg}$ of crop product (Table 2). In our results, the carbon footprints were, in decreasing order, $0.80 \mathrm{~kg} \mathrm{CO} \mathrm{CO}_{2} \mathrm{e}$ for canola, $0.59 \mathrm{~kg} \mathrm{CO}_{2} \mathrm{e}$ for mustard and flaxseed, $0.46 \mathrm{~kg} \mathrm{CO}_{2} \mathrm{e}$ for spring wheat, and $0.20 \sim 0.33 \mathrm{~kg}$ $\mathrm{CO}_{2} \mathrm{e} \mathrm{kg}^{-1}$ of product for pulses grown in the Brown and the Dark Brown soil zones. The carbon footprint for crops produced in the Black soil zone were ranked similarly but had greater magnitude (Table 2). Comparing among soil zones, crops in the Brown soil zone had the lowest yields but the greatest efficiency in terms of lowering carbon footprint per kilogram of crop product (averaging $0.46 \mathrm{~kg} \mathrm{CO}_{2} \mathrm{e} \mathrm{kg}^{-1}$ of grain), whereas the opposite occurred for the Black soil zone where crop yields are general greater but the efficiency is lower and carbon footprints are greater (averaging $0.83 \mathrm{~kg}$ $\mathrm{CO}_{2} \mathrm{e} \mathrm{kg}^{-1}$ of grain). Products from the Dark Brown soil zone are intermediate to the other two (averaging $0.61 \mathrm{~kg} \mathrm{CO}_{2} \mathrm{e}$ $\mathrm{kg}^{-1}$ of grain).

Drinkwater et al. (1998) observed that legume-based cropping systems reduced soil organic carbon and nitrogen losses compared with cereal-based cropping systems. However, numerous studies from the Canadian prairies have shown that the effect of crop species on soil organic carbon was minimal (Liang et al. 2002; Liang et al. 2005; McConkey et al. 2003). Therefore, in our estimation of carbon footprint, the influence of crop species on soil organic carbon is assumed to be quite small compared with the influence of soil $\mathrm{N}$ and other factors.

\subsection{Diversifying cropping systems to reduce carbon footprints}

The adoption of diversified cropping systems can reduce the carbon footprint of crop products. In a field study conducted in southern Saskatchewan, Gan et al. (2003) found that diversified cropping systems compared with monoculture systems significantly reduced the production inputs and increased the grain and straw yields of durum wheat. Thus, compared with monoculture systems, durum wheat grown in diversified cropping systems had a lower carbon footprint (Table 3). Durum wheat preceded by a pulse crop (chickpea, dry pea, or lentil) produced grain with a carbon footprint of $0.200 \mathrm{~kg} \mathrm{CO}_{2} \mathrm{e} \mathrm{kg}^{-1}$ of product, $46 \%$ lower than when preceded by a cereal crop. Furthermore, durum wheat had a carbon footprint of $0.301 \mathrm{~kg} \mathrm{CO}_{2} \mathrm{e} \mathrm{kg}^{-1}$ of grain when grown after an oilseed crop (canola or mustard), 19\% lower than when grown after a cereal. Numerous studies have shown that using improved agronomic practices such as early seeding, optimum plant population density, and proper crop rotation sequences 
Table 4 Reduction in carbon footprints with the use of improved farming systems and crop management practices for the representative oilseed, pulse, and cereal crops in the three soil-climatic zones of the Canadian prairies

Crops and Improved agronomic practices

soil zones

\begin{tabular}{llllll}
\hline $\begin{array}{l}\text { Current no- } \\
\text { till cropping }\end{array}$ & $\begin{array}{l}\text { Improved } \\
\text { agronomic } \\
\text { practices }^{b}\end{array}$ & $\begin{array}{l}\text { N use effic. } \\
\text { increase by } \\
10 \%\end{array}$ & $\begin{array}{l}\text { HI increased by } \\
0.06-0.08 \text { units }^{\text {d }}\end{array}$ & $\begin{array}{l}\text { Use of P- } \\
\text { solubilizer }^{\mathrm{e}}\end{array}$ & $\begin{array}{l}\text { Use of } \\
\text { AM fungi }\end{array}$
\end{tabular}

Total percent of lowered carbon

Carbon footprint, $\mathrm{kg} \mathrm{CO}_{2} \mathrm{e} \mathrm{kg}^{-1}$ of product

\begin{tabular}{|c|c|c|c|c|c|c|c|}
\hline \multicolumn{8}{|c|}{ Brown soil zone } \\
\hline Canola & 0.691 & 0.611 & 0.640 & 0.681 & 0.636 & 0.65 & N/A \\
\hline Dry pea & 0.189 & 0.170 & 0.178 & 0.170 & 0.173 & 0.18 & N/A \\
\hline Spr wheat & 0.383 & 0.339 & 0.354 & 0.377 & 0.352 & 0.36 & $\mathrm{~N} / \mathrm{A}$ \\
\hline \multicolumn{8}{|c|}{ Dark Brown soil zone } \\
\hline Canola & 0.913 & 0.843 & 0.847 & 0.892 & 0.843 & 0.86 & $\mathrm{~N} / \mathrm{A}$ \\
\hline Dry pea & 0.287 & 0.274 & 0.278 & 0.262 & 0.274 & 0.28 & N/A \\
\hline Spr wheat & 0.533 & 0.493 & 0.493 & 0.521 & 0.493 & 0.50 & $\mathrm{~N} / \mathrm{A}$ \\
\hline \multicolumn{8}{|c|}{ Black soil zone } \\
\hline Canola & 0.979 & 0.943 & 0.914 & 0.947 & 0.911 & 0.93 & $\mathrm{~N} / \mathrm{A}$ \\
\hline Dry pea & 0.335 & 0.329 & 0.329 & 0.297 & 0.324 & 0.33 & $\mathrm{~N} / \mathrm{A}$ \\
\hline Spr wheat & 0.560 & 0.540 & 0.522 & 0.542 & 0.521 & 0.53 & $\mathrm{~N} /$ \\
\hline
\end{tabular}

Percent carbon footprint lowered due to improved agronomic practices

Brown soil zone

$\begin{array}{lllrrrrr}\text { Canola } & 0.691 & 11.5 & 7.4 & 1.6 & 8.0 & 5.8 & 34.4 \\ \text { Dry pea } & 0.189 & 10.2 & 6.1 & 10.0 & 8.7 & 7.2 & 42.3 \\ \text { Spr wheat } & 0.383 & 11.5 & 7.5 & 1.6 & 8.0 & 5.7 & 34.3\end{array}$

Dark Brown soil zone

\begin{tabular}{|c|c|c|c|c|c|c|c|}
\hline Canola & 0.913 & 7.6 & 7.2 & 2.2 & 7.6 & 5.5 & 30.1 \\
\hline Dry pea & 0.287 & 4.7 & 3.1 & 8.6 & 4.7 & 3.4 & 24.5 \\
\hline Spr wheat & 0.533 & 7.6 & 7.4 & 2.2 & 7.6 & 5.5 & 30.3 \\
\hline \multicolumn{8}{|c|}{ Black soil zone } \\
\hline Canola & 0.979 & 3.6 & 6.6 & 3.2 & 6.9 & 5.0 & 25.4 \\
\hline Dry pea & 0.335 & 1.7 & 1.7 & 11.3 & 3.3 & 2.4 & 20.5 \\
\hline Spr wheat & 0.560 & 3.6 & 6.8 & 3.2 & 6.9 & 5.0 & 25.5 \\
\hline
\end{tabular}

${ }^{a}$ Commonly used no-till management systems in the production of canola, dry pea, and spring wheat on the Canadian prairie (Gan et al. 2003; Miller et al. 2003);

${ }^{\mathrm{b}}$ Improved agronomic practices such as the use of early seeding, optimum crop rotation sequences, and best pest management practices (Gan et al. 2010; Kirkegaard et al. 2008; Menalled et al. 2001);

${ }^{\mathrm{c}} \mathrm{N}$ use efficiency to be increased by $10 \%$ (conservatively), through improved $\mathrm{N}$ fertilizer application technology such as side-banding, timely application, site-specific approaches (Malhi et al. 2001; Peng et al. 2010; Sieling and Kage 2010)

${ }^{\mathrm{d}}$ Harvest index to be increased by $0.06-0.08$ units from the current level though adaptation of new cultivars such as hybrid canola, semi-leafless dry pea, and short-statues of spring wheat (Annicchiarico et al. 2005; Malhi et al. 2001; Moot and McNeil 1995)

${ }^{\mathrm{e}}$ Use of P. bilaii fungus has been shown to increase crop productivity in canola, dry pea, and spring wheat by an average of 7\% (Gan et al. 2010; Zhang and Smith 1997)

${ }^{\mathrm{f}}$ Arbuscular mycorrhizal (AM) fungi are increasingly used in crop production to improve plant development and health and increase phytoremediation (Gianinazzi and Vosátka 2004; Miransari and Smith 2009; Paradis et al. 1995)

can increase crop yields without increasing production input (Gan et al. 2010; Kirkegaard et al. 2008; Menalled et al. 2001; Miller et al. 2003). The intensity of yield increases due to improved crop management is usually greater in the Brown soil zone than in the Dark Brown and Black soil zones. In our calculation of the carbon footprint for some representative crop species, the improved agronomic practices can potentially lower the carbon footprint of canola, spring wheat, and dry pea by an average of $11 \%$ in the Brown, $7 \%$ in the Dark Brown, and 3\% in the Black soil zones (Table 4).

Herbicides remain the most commonly used weed management practice (Beckie 2007). In the northern Great Plains of North America, for example, herbicides com- 
Fig. 1 Conventional and diversified rotations differ in the type and timing of weed management practices (symbols), seeding dates, and canopy characteristics and closure times (lines). In the diversified rotations, the continuous variations in herbicides, canopies, and seeding dates makes it very difficult for a specific weed to adapt to the changing environmental conditions (adopted from Gan et al. 2010)

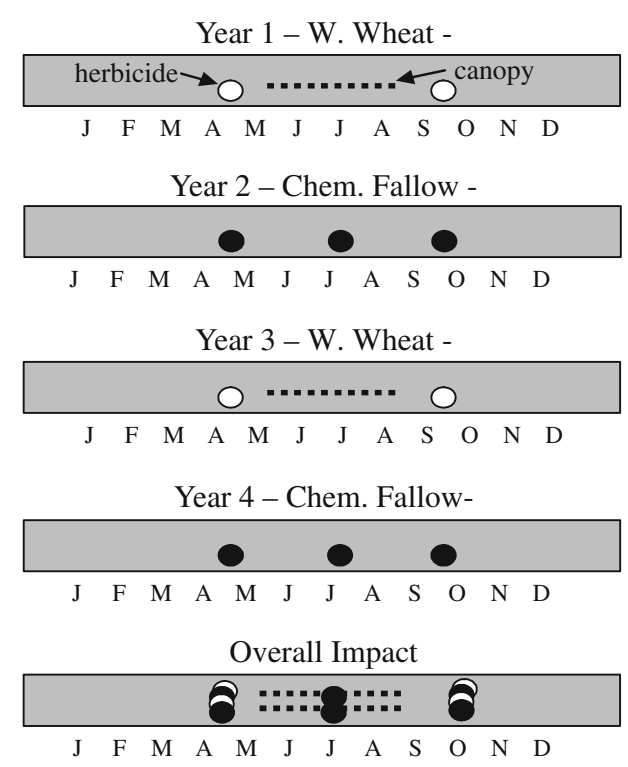

Conventional Wheat-Fallow

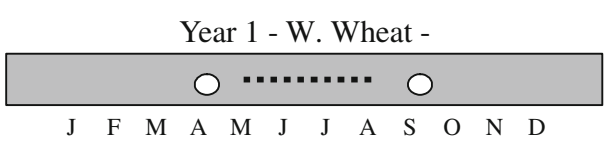

Year $2-$ Ch. Pea-

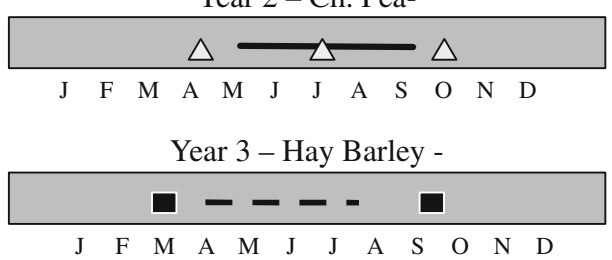

Year 4 - Chem. Fallow -

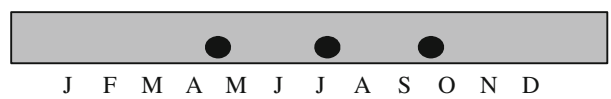

Overall Impact

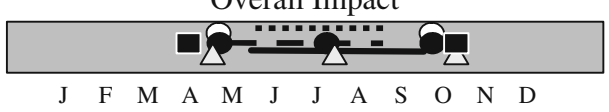

Diversified Rotation prise approximately $85 \%$ of the pesticide input in cereal crop production (Derksen et al. 2002). Weed management through the adoption of diverse cropping systems has been recognized as a key component in the development of sustainable agricultural systems (Menalled et al. 2001). In diversified crop sequences, weeds are exposed to a wide range of causes of mortality. A myriad of stresses are imposed on the weeds by growing crops with different planting and harvesting dates, different morphology and phenology, competitive characteristics, and crop residues (Fig. 1). With increased crop diversification in a rotation, weeds are subjected to an increased diversity of control methods, including timing and intensity of tillage and/or herbicide application, wider spectrum of herbicides, and varying degrees of crop competitiveness. These changes from one crop species to another generate microenvironments that do not favor the establishment and proliferation of any one particular weed species. As a consequence, crop diversification reduces weed abundance (Westerman et al. 2005) and herbicide input (Harker et al. 2009), and increases crop productivity (Menalled et al. 2001).

Integrating various cultural practices will significantly reduce herbicide input in crop production (Harker et al. 2009). For example, a high-management package (i.e., greater competitive cultivars, higher-than-normal seeding rates, and rotating cereal with oilseed crops) coupled with a half rate $(1 / 2 \times)$ of herbicides achieved a level of wild oat control similar to a low-management package (i.e., lower competitive cultivars, normal to lower seeding rates, and cereal monoculture) coupled with a full rate $(1 \times)$ of herbicide (Harker et al. 2009). Furthermore, wild oat seed production at $1 / 4 \times$ rate was reduced by $94 \%$ when competitive (tall) barley cultivars were seeded at double the seeding rate and rotated with canola and field pea, compared with continuously planting short barley cultivars at normal rates. At the quarter herbicide rate, wild oat biomass was reduced two-, six-, or 19-fold, respectively, when the accompanying crop was grown using one, two, and three components of the management package. These results indicate that using diversified cropping systems can substantially reduce pesticide input in crop production and thus reduce the carbon footprint of the crop products. Even though pesticides are a small contributor to the estimate of a carbon footprint (data not shown), optimizing crop health with improved agronomic management creates opportunities for improving crop productivity while further reducing carbon footprints in the production of field crops (Table 4).

\subsection{Including biological $\mathrm{N}$-fixation to reduce the input of synthetic $\mathrm{N}$ fertilizer}

The Haber-Bosch process of industrial $\mathrm{N}_{2}$-fixation is energy intensive. In Canada, for example, natural gas used in industrial $\mathrm{N}_{2}$-fixation accounts for about $70 \%$ of the cost of $\mathrm{N}$ fertilizer (Agriculture and Agri-Food Canada AAFC 2009). Manufacturing the $620,285 \mathrm{t}$ of $\mathrm{N}$ fertilizer applied in the Canadian Prairie Provinces in a single growing season releases about 15.7 million tonnes $\mathrm{CO}_{2} \mathrm{e}$, and transporting the $\mathrm{N}$ fertilizer further increases $\mathrm{CO}_{2}$ emissions. Using biological $\mathrm{N}$-fixation through the inclusion of pulse crops in crop rotations can reduce the dependence of agriculture on synthetic $\mathrm{N}$ fertilizers (Crews and Peoples 2004) and thus reduce agricultures carbon footprint. Studies 
Table 5 Estimates of the contribution of various pulses to the global input of biological $\mathrm{N}_{2}$-fixation to soil (adopted from Herridge et al. 2008), minimum level of $\mathrm{N}$ derived from $\mathrm{N}$ fixation (Ndfa) necessary for a positive contribution to soil $\mathrm{N}$ from pulse crops expressed as kilograms of fixed-N per hectare and as percent of fixed-N in the pulse crop, as compared with mean Ndfa observed in the Northern Great Plains (adopted from Walley et al. 2007)

\begin{tabular}{|c|c|c|c|c|}
\hline \multirow[t]{2}{*}{ Pulse species } & \multirow[t]{2}{*}{ Global $\mathrm{N}$ contribution $\left(\mathrm{kg} \mathrm{N} \mathrm{ha}^{-1}\right.$ year $\left.^{-1}\right)$} & \multicolumn{2}{|c|}{$\begin{array}{l}\text { Minimum Ndfa required for a positive } \\
\text { contribution to soil } \mathrm{N}\end{array}$} & \multirow[t]{2}{*}{ Mean Ndfa ( $\%$ of total $\mathrm{N}$ uptake) } \\
\hline & & $\left(\mathrm{kg} \mathrm{N} \mathrm{ha}^{-1}\right)$ & (\% of total $\mathrm{N}$ uptake) & \\
\hline Common bean & 23 & 49.5 & 52.1 & 40.7 \\
\hline Chickpea & 58 & 37.4 & 56.1 & 50.0 \\
\hline Dry pea & 86 & 68.4 & 46.7 & 52.4 \\
\hline Lentil & 51 & 47.3 & 47.8 & 57.9 \\
\hline Faba bean & 107 & 85.7 & 65.3 & 84.1 \\
\hline Groundnut & 88 & N/A & N/A & N/A \\
\hline Soybean & 176 & N/A & N/A & N/A \\
\hline Other pulses & 41 & $\mathrm{~N} / \mathrm{A}$ & N/A & $\mathrm{N} / \mathrm{A}$ \\
\hline
\end{tabular}

$N A$ not available

have shown that $\mathrm{N}$ use efficiency can be increased substantially simply through improved $\mathrm{N}$ fertilizer application technology such as side-banding, timely application, site-specific approaches (Malhi et al. 2001; Peng et al. 2010; Sieling and Kage 2010). In our estimate, if $\mathrm{N}$ use efficiency can be increased by $10 \%$, which is highly possible using improved $\mathrm{N}$ management practices, the carbon footprint of canola and wheat, two N-loving crops, can be decreased by 7\% (Table 4). Also, legume-rhizobial associations are effective solar-driven $\mathrm{N}_{2}$-fixing systems in which atmospheric $\mathrm{N}_{2}$ is transformed into ammonia, without net $\mathrm{CO}_{2}$ emissions.

In addition to fixing their $\mathrm{N}$ requirements, pulse crops leave a portion of their biologically fixed-N in the soil (Table 5). The contribution of rhizodeposition, roots, and nodules that remained in the soil after harvest was often ignored leading to underestimation of the real contribution of biologically fixed-N by pulses. For example, chickpea, once considered a poor contributor to soil $\mathrm{N}$ with an $\mathrm{N}$ balance close to zero, enriches the soil $\mathrm{N}$ pool with annual contributions at $58 \mathrm{~kg} \mathrm{ha}^{-1}$ (Table 5), and this number can be even greater when the release of mineralized-N from roots and nodules is accounted for (Khan et al. 2003; Herridge et al. 2008).

Large amounts of $\mathrm{N}$ are exported from farm fields in legume grain. To meet the demand for $\mathrm{N}$ by the plants for their growth and development, as well as making positive contributions to soil $\mathrm{N}$, pulse plants need to fix a substantial amount of $\mathrm{N}$ from the atmosphere ( $\mathrm{Ndfa}$ ) via $\mathrm{N}$-fixation. Often, growing conditions such as drought and elevated soil nitrate levels negatively impact nitrogenase activity in pulse nodules (Marino et al. 2009) and therefore, reduce Nfixation (Walley et al. 2007). The effect, however, varies with crop species; lentil and dry pea tend to fix more $\mathrm{N}$ thus contributing greater amounts of $\mathrm{N}$ to the soil than common bean and chickpea (Table 5).

Not only do pulses fulfill their $\mathrm{N}$ requirement through biological $\mathrm{N}_{2}$-fixation and thus reduce $\mathrm{N}$ fertilizer use in agricultural systems, but also pulses enhance the productivity of subsequent crops through other undetermined means (Gan et al. 2003; Kirkegaard et al. 2008). Globally, pulses contribute about 21 million tonnes of fixed-N per year, accounting for one third of the total biological $\mathrm{N}_{2}$ fixation in agroecosystems (Herridge et al. 2008). This contribution can be further improved by increasing the frequency of pulses in cropping rotations, reducing the negative impact of high residual soil $\mathrm{N}$ on $\mathrm{N}_{2}$-fixation and improving the synchrony between $\mathrm{N}$ mineralization from pulse residue and the peak $\mathrm{N}$ demand of the following crop (Marino et al. 2009; Sieling and Kage 2010).

3.4 Improving nutrient use efficiency using biotechnologies valorizing soil microbial resources

Abundant use of fertilizer in agriculture often causes environmental problems including $\mathrm{N}_{2} \mathrm{O}$ emissions (Van Noordwijk and Cadisch 2002), largely because the recovery rates of fertilizer $\mathrm{N}, \mathrm{P}$, and $\mathrm{K}$ by crops are as low as $50 \%$, $25 \%$, and 40\%, respectively (Prasad 2009). Soil microbial resources can be used to improve the use efficiency of these nutrients as several fungi and bacteria interact with the growth of plant roots (Fig. 2), and function as biofertilizers and biopesticides (Hynes et al. 2008).

Soil microorganisms, such as arbuscular mycorrhizal fungi (AM fungi), $P$ solubilizing fungi and bacteria, and $\mathrm{N}_{2}$-fixers, can enhance plant nutrition and improve plant growth through the induction of changes in plant metabo- 
Fig. 2 Interactions among plant-growth-promoting-microorganisms and the growth and development of field crops (modified from Avis et al. 2008)

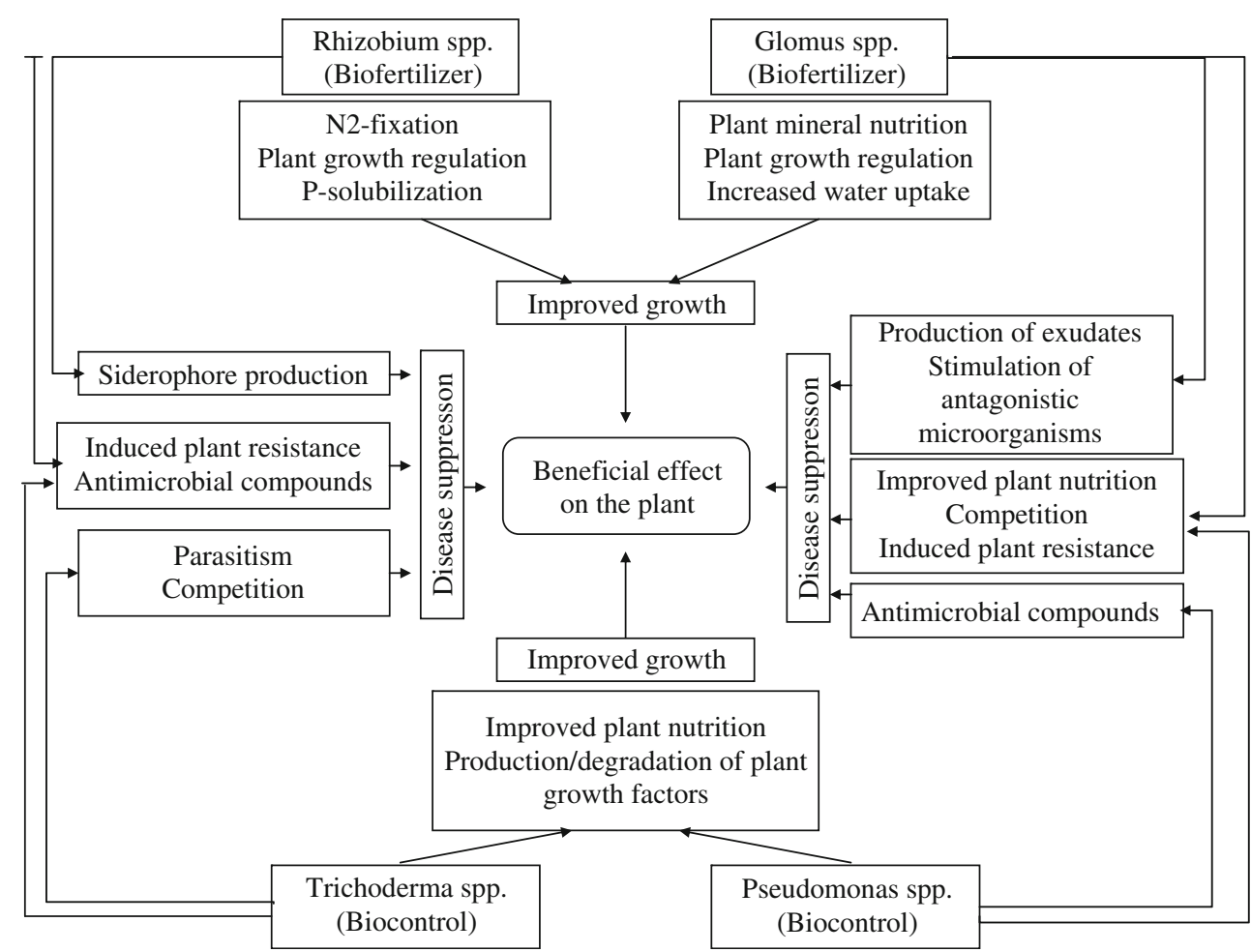

lism. Many bacteria can produce auxins, gibberellins, cytokinins, and ethylene in amounts stimulating plant growth, increasing root branching or shoot development (Van Loon 2007). A long list of plant-growth-promoting rhizobacteria can be isolated from field crops in the prairie ecozone (Hynes et al. 2008). Several bacteria possess the enzyme 1-aminocyclopropane-1-carboxilic acid (ACC) deaminase and use ACC, the precursor of ethylene, as a source of food. They remove ACC from the rhizosphere, stimulating root elongation and plant growth in the process. The AM fungi are also known to reduce the impact of environmental stresses caused by toxic metals (Audet and Charest 2008), high temperature (Paradis et al. 1995), and severe drought (Augé 2001) in their host plants by improving hormone production, binding metals, modifying electrolyte concentration in plant cytoplasm, and extracting water from the soil (Hynes et al. 2008). Other endophytic fungi (i.e., dark septate endophytes) are emerging as important plant associates. The abundance of these endophytes can improve drought tolerance of their host plants in stressful environments (Yuan et al. 2010).

Biopesticides involve bacteria as well as fungi. Whereas AM fungi can "sanitize" the rooting soil through baiting and nutritional interactions (St-Arnaud et al. 1996), other organisms such as Trichoderma are toxin-producing antagonists (Reino et al. 2008). Pseudomonas fluorescens also inhibit soil-borne pathogens through siderophore-related sequestration of $\mathrm{Fe}$ and starvation (Choudhary et al. 2009). Microorganisms can also influence gene expression and activate or "prime" plant defense mechanisms through systemic acquired resistance (SAR) and systemically induced resistance (SIR) to pathogens (Van Loon 2007). SAR and SIR operate through production of signaling compounds by plant-growth-promoting rhizobacteria, and plants may produce bioactive molecules, in a two-way process paralleling legume-rhizobia cross-talk (Van Loon 2007), opening the possibility of manipulating plant disease resistance with manufactured signal molecules. Compounds acting on microbial associates of plants could be used to manage crop rhizosphere and reduce the amount of agrochemical used on-farm, as minute amounts of these signal molecules are required for bioactivity, thus reducing the carbon footprint of crops.

Opportunities for rhizosphere management are offered by the discovery of bioactive molecules. Research has shown that flavonoids produced in minute amounts by legume plants were involved in the induction of nodulation (Rolfe 1988). Genistein, a flavonoid produced by soybean, turns on nod genes in Bradyrhizobium japonicum, initiating the process of nodulation in the plant (Zhang and Smith 1997). This discovery led to the formulation of genisteinamended soybean inoculants for early nodulation in cool soils (Leibovitch et al. 2001). Lipochito-oligosaccharides (LCO) produced by B. japonicum is responsive to host plant signal and acts as a plant-growth promoter (Miransari and Smith 2009). LCOs have been commercialized as LCO Promoter Technology ${ }^{\mathrm{TM}}$ for use in corn and soybean production.

The AM fungi symbiosis in plants is also stimulated by flavonoids such as formononetin, biochanin-A (Fries et al. 
1998), and eupalitin (Cruz et al. 2004). Formononetinbased technology is commercialized as Myconate ${ }^{\circledR}$, in different formulations, as a stimulant for mycorrhizal development. Several compounds are involved in the regulation of the AM symbiosis. Arbuscular mycorrhizal fungi were shown to be influenced by the polyamines putrescine and spermidine (El et al. 1996), the nucleoside derivative 5'-deoxy-5'-methylamino-adenosine (Kuwada et al. 2006), and by tryptophan dimer, a peptide (Horii et al. 2009).

Whereas signal molecules can be manufactured and applied in inoculants or directly on plants, a more interesting approach for farmers would be the selection of crop genotypes with better host quality to valorize existing soil bioresources. The genetic variability necessary for the selection of plant genotypes forming effective symbioses with AM fungi exists (Sawers et al. 2010) and breeding programs targeting better symbiosis in wheat have been undertaken at least in Canada and Europe. Efficiency of nutrient acquisition has rarely been considered. In fact, breeding under conditions of nutrient abundance may have selected against efficient nutrient acquisition and nutrient providing plant symbioses (Lynch 2007). Little effort has been made in the selection of plants for superior symbiotic performance in crops other than legumes. Yet, plant symbioses have the potential to improve crop performance through better tolerance to drought stress and protection against disease organisms, in addition to promoting efficient nutrient acquisition (Afza et al. 2010). These strategies and practices of utilizing plant symbioses to improve nutrient use efficiency will be critically important in reducing carbon footprints in agriculture. For example, the use of Penicillium bilaii, a P-solublizing fungus, along with AM fungi, has been shown to improve plant health, enhance plant phytoremediation, and increase crop yield in canola and wheat by $7 \%$ to $30 \%$ (Gianinazzi and Vosátka 2004; Miransari and Smith 2009; Paradis et al. 1995; Zhang and Smith 1997). Based on the low end of the increased crop productivity (conservatively), we estimate that the carbon footprint of canola and wheat can be lowered by $13 \%$ with the application of P-solublizing fungi and AM fungi (Table 5).

\subsection{Cropping systems and energy use efficiency}

in the semiarid Canadian prairie

The burning of fossil fuels is an obvious and major form of energy input into agriculture (Zentner et al. 2009). Fossil fuels are used to power farm machinery used in various farming operations such as seeding, cultivating, spraying, harvesting, haying, crop drying, transporting products to markets, etc. Fossil fuels are also used in the manufacture and repair of farm machinery and the manufacture and transport of fertilizers, pesticides and other crop inputs (Janzen et al. 1998). Energy input to agricultural systems depends upon numerous factors, two of which are tillage management and crop rotation including cropping intensity and crop diversity (Zentner et al. 2009). Management practices include intensity of tillage - conventional (such as summerfallowing or several tillage operations for weed control, seedbed preparation, seeding), conservational (reduced, minimum, and no-till systems), organic (intensive tillage for seeding, weed control, trash management). Conventional and conservational management systems use fertilizers for nutrient replenishment and pesticides for weed, insect and disease control, whereas organic management includes non-chemical pest control and legumes as well as manures for nutrient replenishment. Crop diversity ranges from low intensity diversification (such as monoculture cereal-based cropping systems often including summerfallow) to higher intensity diversification such as rotations using annual cereal, oilseed, and pulse crops, or rotations including annual crops and perennial forages.

Generally, there is little difference in total energy use by conventional compared with conservational cropping systems (Table 6; Zentner et al. 1989, 2009). Energy use in the form of fuel and machinery is lower for no-till directseeding compared with conventional tillage practices. However, in order to respond to the increased soil water reserves often associated with reduced tillage systems, fertilizer and pesticide application rates are often increased. Thus, energy use in the production and distribution of pesticides and fertilizers, especially $\mathrm{N}$, is higher for directseeding compared with conventional production systems. In contrast, savings in energy input are significantly higher with organic systems because of the non-use of pesticides or inorganic fertilizers (Table 6; Hoeppner et al. 2006; Zentner et al. 2009).

In annual crops, production practices that reduce the application rate of fertilizer $\mathrm{N}$ decrease the energy input to the system (Zentner et al. 1989) and thus will reduce the carbon footprint of crop products significantly (Table 4). More diversified rotations that include pulse crops along with cereals reduce energy requirements because the nitrogen-fixation capabilities of the pulses reduce the overall fertilizer $\mathrm{N}$ requirements for the rotation. Cerealoilseed rotations usually have higher energy requirements than cereal-pulse rotations mainly because oilseeds require fertilizer $\mathrm{N}$ while pulses supply $\mathrm{N}$ by symbiosis (Table 5 ).

On the Canadian prairie, energy use efficiency (EUE), yield per unit energy input or the ratio of energy output (yield of grain and forage) to energy input, is highest for organic systems and lower but similar for conventional and conservational systems (Table 6; Hoeppner et al. 2006; Zentner et al. 2009). For example, average yields of annual crops on organic farms in the eastern and central 
Table 6 Average annual production, total energy input, energy output, net energy production, and energy use efficiency measured as grain yield per unit energy input and as the ratio energy output/ energy input for conventional, conservational, and organic cropping systems in the Canadian Prairies

\begin{tabular}{|c|c|c|c|c|c|c|c|}
\hline $\begin{array}{l}\text { Cropping } \\
\text { system }\end{array}$ & $\begin{array}{l}\text { Yield, kg } \\
\text { ha }^{-1} \text { year }^{-1}\end{array}$ & $\begin{array}{l}\text { Energy input, } \\
\text { MJ ha }^{-1} \text { year }^{-1}\end{array}$ & $\begin{array}{l}\text { Energy output, } \\
\mathrm{MJ} \mathrm{ha}^{-1} \text { year }^{-1}\end{array}$ & $\begin{array}{l}\text { Net energy, MJ } \\
\text { ha }^{-1} \text { year }^{-1}\end{array}$ & $\begin{array}{l}\text { Yield/energy, kg } \\
\text { ha }^{-1} \mathrm{GJ}^{-1} \text { year }^{-1}\end{array}$ & $\begin{array}{l}\text { Energy out/ } \\
\text { energy in }\end{array}$ & Source \\
\hline Conventional & 1,472 & 3,856 & 26,541 & 22,687 & 391 & 6.88 & Zentner et al. 2009 \\
\hline Conservational & 1,419 & 3,854 & 25,592 & 21,737 & 375 & 6.64 & $(1996-2007)$ \\
\hline Organic & 940 & 1,889 & 16,600 & 14,711 & 497 & 8.79 & \\
\hline Conventional & & 4,906 & 58,466 & & & 11.9 & Hoeppner et al. 2006 \\
\hline Organic & & 1,934 & 41,428 & & & 21.4 & $(1992-2003)$ \\
\hline Conventional & & 7,157 & 37,989 & 30,832 & 321 & 5.31 & Zentner et al. 2004 \\
\hline Conservational & & 7,171 & 39,287 & 32,111 & 324 & 5.48 & (1987-1998) \\
\hline Conventional & & 4,038 & 21,073 & 17,035 & 406 & 5.22 & Zentner et al. 1998 \\
\hline Conservational & & 4,374 & 20,606 & 16,232 & 364 & 4.71 & (1982-1993) \\
\hline
\end{tabular}

Also identified are the duration of the study and the publication from which the data was obtained

prairies are typically lower than on conventional farms (Entz et al. 2000; Zentner et al. 2009). However, energy inputs are much lower on organic farms contributing to the higher EUE. Organically, managed crop rotations that include annual and perennial forage crops have the highest energy use efficiencies. This practice is especially advantageous in semiarid areas where yield reduction from pest infestations is usually less severe compared with more humid and subhumid regions. Using our model, we estimated that the carbon footprint of canola produced under organic systems in the semiarid Brown soil zone was $0.18 \mathrm{~kg} \mathrm{CO}_{2} \mathrm{e} \mathrm{kg}^{-1}$ of product, about one third of the carbon print of canola produced under conservation systems $\left(0.69 \mathrm{~kg} \mathrm{CO}_{2} \mathrm{e} \mathrm{kg}^{-1}\right)$. Similarly, spring wheat produced under the organic systems in the semiarid Brown soil zone had a carbon footprint of $0.11 \mathrm{~kg} \mathrm{CO}_{2} \mathrm{e} \mathrm{kg}{ }^{-1}$, significantly lower than $0.38 \mathrm{~kg} \mathrm{CO}_{2} \mathrm{e} \mathrm{kg}^{-1}$ when produced under conservation systems.

Overall, fossil fuel use in agriculture is a relatively small part of the emissions from Canadian farms compared with on-farm sources of methane and nitrous oxide (Janzen et al. 2006). About $2.8 \%$ of the national energy consumption from 1997 to 2003 was used in agricultural production (Dyer and Desjardins 2006). Because of the low profile of farm energy use on the scale of climate change issues, policy-makers, and researchers are often linking farm fuel use with other relevant sectors such as transportation of farm fertilizers and machinery (Dyer and Desjardins 2007).

\subsection{Improving crop residue management in farming systems}

Crop residues produced worldwide are estimated at 2,962 million tonnes, equivalent to 1,333 million tonnes of carbon, per year (Lal 1995). Proper management of crop residue will improve agricultural productivity and reduce the carbon footprint of crop products. Crop residues retained on the soil surface, through the use of conservation tillage, can provide the following benefits: increase carbon sequestration of atmospheric $\mathrm{CO}_{2}$ into soils (VandenBygaart et al. 2003); reduce fuel use and greenhouse gas emissions (West and Marland 2002); protect the soil surface from water and wind erosion and thus reduce fertilizer input (Unger 1978; Malhi et al. 2001); improve soil aggregate stability, rainfall capture efficiency, and water holding capacity (Campbell et al. 1995, 1989); improve biodiversity both above and below ground (Swift et al. 1996); improve plant-mycorrhizae associations (McGonigle and Miller 1993); and lower nitrous oxide emissions (Ussiri et al. 2009). Also, crop residue can be incorporated into the near-surface soil using conventional or strip tillage practices (Al-Kaisi and Licht 2004). When crop residues are incorporated deeper into the sub-soil horizons, carbon placed beneath the plow layer will decompose very slowly because of reduced exposure to climatic elements. Also, growing deep-rooted plants has been shown to improve soil structure and increase soil carbon in the subsoil horizons.

Biochar is a charcoal made by heating biomass under oxygen-limited conditions (e.g., slow pyrolysis). Charcoal is a stable solid rich in carbon and can be used to lock carbon in the soil. Since biochar can sequester carbon in the soil for hundreds to thousands of years, it has received considerable interest as a potential tool to sequester atmospheric carbon. As well, recent research has shown that the use of biochar can reduce leaching, increase the availability of nutrients for plant growth, reduce the amount of fertilizer required in crop production, and decrease nitrous oxide and methane emissions (Laird et al. 2009).

With regards to crop residue management, numerous studies from the Canadian prairies have shown that soil 
organic matter is largely influenced by tillage and crop rotations (summerfallow versus no-till cropping) and less influenced by crop species (Liang et al. 2002; Liang et al. 2005; McConkey et al. 2003).

\section{Conclusions}

In this paper, we estimated the relative intensities of greenhouse gas emission from the production of various field crops grown on the Canadian prairie and determined the effect of soil-climatic conditions, crop species, and different cropping systems on the carbon footprint of a crop product. Based on the model we developed, field crops grown in the more humid Black soil zone had substantially greater carbon footprint than the crops grown in the drier Brown and Dark Brown soil zones. Under the same growing conditions, canola and wheat had significantly greater carbon footprint than pulse crops (chickpea, dry pea, lentil). Durum wheat grown in diversified cropping systems had a lower carbon footprint than when grown in cereal monoculture systems. This information is critical for establishing inventories of greenhouse gas emissions from cropping systems involving cereals, oilseeds, and pulse crops. We identified major strategies and practices for potentially lowering the carbon footprint of field crops grown in semiarid regions. With the model we developed, the carbon footprint of major field crops grown on the Canadian prairie can be collectively lowered as much as $24 \%$ in the Black, $28 \%$ in the Dark Brown, and $37 \%$ in the Brown soil zones. These percentage decreases are very conservative and can be achieved during crop production through adoption of agronomic practices that, for example, increase $\mathrm{N}$ use efficiency, grow crop cultivars with high harvest index, and use soil bioresources such as Psolublizers and arbuscular mycorrhizal fungi. To our knowledge, this information is unique and potentially useful as a reference source for policy-makers and crop modelers who are interested in estimating the carbon footprint of various cropping systems or estimating sectorwide commodity-specific emissions. The absolute value of the estimated carbon footprint will change depending on crop productivity, cropping system, and associated production inputs, especially the rate of nitrogen fertilizer, and farm operations such as tillage and crop residue management.

We must realize that the concept of carbon footprint is still relatively new. There is a lack of knowledge about emissions from the various activities in the value chain for food production, processing, and marketing. More detailed studies on life cycle assessment would help evaluate how different cropping options and varying agricultural ecosystems would affect the carbon footprint of a crop product and of the emissions along the value chain of food processing and marketing. Some quantitative estimates of the impacts of agricultural ecosystems on environmental variables in the upstream and downstream processes need to be considered when estimating the carbon footprint of a crop product. Furthermore, the methodology for calculation of carbon footprints varies between sectors or between different ecosystems. The carbon footprint estimated for a food product can be affected by the process of production, climatic conditions under which the product is grown, and the process for delivery of the product to market after leaving the farm gate. These and other challenges make it difficult to adequately calculate carbon footprint in some cases. Also, there is a need to develop a common methodology to document detailed emissions at each level in the production cycle, so that all emissions along with the entire food chain can be synthesized into the calculation of the carbon footprint.

\section{References}

Afza A, Bano A, Fatima M (2010) Higher soybean yield by inoculation with $\mathrm{N}$-fixing and P-solubilizing bacteria. Agron Sustain Dev 30:487-495. doi:10.1051/agro/2009041

Agriculture and Agri-Food Canada (AAFC) (2009) North American Fertilizer Prices, Production and Consumption, in: Korol M., Larivière É. (Eds.), Fertilizer Pricing in Canada, http://www4.agr. gc.ca/AAFC-AAC/display-afficher.do?id=1179252532274\&lan $\mathrm{g}=$ eng\#table 3.9

Al-Kaisi M, Licht MA (2004) Effect of strip tillage on corn nitrogen uptake and residual soil nitrate accumulation compared with notillage and chisel plow, Agron J 96:1164-1171

Annicchiarico P, Abdellaoui Z, Kelkouli M, Zerargui H (2005) Grain yield, straw yield and economic value of tall and semi-dwarf durum wheat cultivars in Algeria. J Agric Sci 143:57-64

Audet P, Charest C (2008) Allocation plasticity and plant-metal partitioning: Meta-analytical perspectives in phytoremediation. Environ Pollut 156:290-296

Augé RM (2001) Water relations, drought and vesicular-arbuscular mycorrhizal symbiosis. Mycorrhiza 11:3-42

Avis TJ, Gravel V, Antoun H, Tweddell RJ (2008) Multifaceted beneficial effects of rhizosphere microorganisms on plant health and productivity. Soil Biol Biochem 40:1733-1740

Beckie HJ (2007) Beneficial management practices to combat herbicide-resistant grass weeds in the northern Great Plains. Weed Technol 21:290-299

Campbell CA, Biederbeck VO, Schnitzer M, Selles F, Zentner RP (1989) Effect of 6 years of zero tillage and $\mathrm{N}$ fertilizer management on changes in soil quality of an Orthic Brown Chernozem in southwestern Saskatchewan. Soil Tillage Res 14:39-52

Campbell CA, McConkey BG, Zentner RP, Dyck FB, Selles F, Curtin D (1995) Carbon sequestration in a Brown Chernozem as affected by tillage and rotation. Can J Soil Sci 75:449-458

Campbell CA, Zentner RP, Gameda S, Blomert B, Wall DD (2002) Production of annual crops on the Canadian prairies: Trends during 1976-1998. Can J Soil Sci 82:45-57

Choudhary DK, Prakash A, Wray V, Johri BN (2009) Insights of the fluorescent pseudomonads in plant growth regulation. Curr Sci India 97:170-179 
Crews TE, Peoples MB (2004) Legume versus fertilizer sources of nitrogen: ecological tradeoffs and human needs. Agric Ecosys Environ 102:279-297

Cruz AF, Ishii T, Matsumoto I, Kadoya K (2004) Relationship between arbuscular mycorrhizal fungal development and eupalitin content in bahiagrass roots grown in a satsuma mandarin orchard. J Japan Soc Hortic Sci 73:529-533

Derksen DA, Anderson RL, Blackshaw RE, Maxwell B (2002) Weed dynamics and management strategies for cropping systems in the northern Great Plains. Agron J 94:174-185

Dobbie KE, McTaggart IP, Smith KA (1999) Nitrous oxide emissions from intensive agricultural systems: Variations between crops and seasons, key driving variables, and mean emission factors. J Geophys Res Atmos 104:26891-26899

Drinkwater LE, Wagoner P, Sarrantonio M (1998) Legume-based cropping systems have reduced carbon and nitrogen losses. Nature 396:262-265

Dyer JA, Desjardins RL (2006) Carbon dioxide emissions associated with the manufacturing of tractors and farm machinery in Canada. Biosyst Eng 93:107-118

Dyer JA, Desjardins RL (2007) Energy-based GHG emissions from Canadian agriculture. J Energy Inst 80:93-95

Dyer J.A., Vergé X.P.C., Desjardins R.L., Worth E.D., McConkey B. G. (2010) The impact of increased biodiesel production on the greenhouse gas emissions from field crops in Canada, Energy Sust. Devel. (in press).

El GN, Paynot M, Martin-Tanguy J, Morandi D, Gianinazzi S (1996) Effect of polyamines and polyamine biosynthesis inhibitors on spore germination and hyphal growth of Glomus mosseae. Mycol Res 100:597-600

Entz MH, Guilford R, Gulden R (2000) Crop yield and soil nutrient status on 14 organic farms in the eastern portion of the northern Great Plains. Can J Plant Sci 81:351-354

Environment Canada. (2010) National Inventory submission: Greenhouse Gas Sources and Sinks in Canada, Greenhouse Gas Division, Environment Canada, Ottawa, ON. http://unfecc.int/ national_reports/annex_i_ghg_inventories/national_inventories_ submissions/items/5270.php

Flynn HC, Smith J, Smith KA, Wright J, Smith P, Massheder J (2005) Climate- and crop-responsive emission factors significantly alter estimates of current and future nitrous oxide emissions from fertilizer use, Glob. Change Bio 11:1522-1536

Forster P, Ramaswamy V, Artaxo P, Berntsen T, Betts R, Fahey DW, Haywood J, Lean J, Lowe DC, Myhre G (2007) Changes in Atmospheric Constituents and in Radiative Forcing. In: Solomon S, Qin D, Manning M, Chen Z, Marquis M, Averyt KB, Tignor M, Miller HL (eds) Climate Change 2007: The Physical Science Basis. Contribution of Working Group I to the Fourth Assessment Report of the Intergovernmental Panel on Climate Change. Cambridge University Press, New York, pp 129-234

Fries LLM, Pacovsky RS, Safir GR (1998) Influence of phosphorus and formononetin on isozyme expression in the Zea maysGlomus intraradices symbiosis. Physiol Plantarum 103:172-180

Gan YT, Miller PR, McConkey BG, Zentner RP, Stevenson FC, McDonald CL (2003) Influence of diverse cropping sequences on durum wheat yield and protein in the semiarid northern Great Plains. Agron J 95:245-252

Gan YT, Campbell CA, Jansen HH, Lemke R, Liu LP, Basnyat P, McDonald CL (2009) Carbon input to soil by oilseed and pulse crops in semiarid environment. Agric Ecosys Environ 132:290 297

Gan YT, Kutcher R, Menalled F, Lafond L, Brandt S (2010) Crop diversification and intensification with broadleaf crops in cerealbased cropping systems in the Northern Great Plains of North America. In: Malhi SS, Gan YT, Schoenau JJ, Lemke RL, Liebig MA (eds) Recent Trends in Soil Science and Agronomy Research in the Northern Great Plains of North America. Research Signpost, Trivandrum, Kerala, India, p 427

Gianinazzi S, Vosátka M (2004) Inoculum of arbuscular mycorrhizal fungi for production systems: science meets business. Can J Bot $82: 1264-1271$

Harker KN, O'Donovan JT, Irvine RB, Turkington TK, Clayton GW (2009) Integrating cropping systems with cultural techniques augments wild oat (Avena fatua) management in barley. Weed Sci 57:326-337

Herridge DF, Peoples MB, Boddey RM (2008) Global inputs of biological nitrogen fixation in agricultural systems. Plant Soil 311:1-18

Hoeppner JW, Entz MH, McConkey BG, Zentner RP, Nagy CN (2006) Energy use and efficiency in two Canadian organic and conventional crop production systems. Renew Agric Food Syst 21:60-67

Horii S, Matsumura A, Kuramoto M, Ishii T (2009) Tryptophan dimer produced by water-stressed bahia grass is an attractant for Gigaspora margarita and Glomus caledonium. World J Microbiol Biotechol 25:1207-1215

Hynes RK, Leung GCY, Hirkala DLM, Nelson LM (2008) Isolation, selection, and characterization of beneficial rhizobacteria from pea, lentil, and chickpea grown in western Canada. Can J Microbiol 54:248-258

IPCC. (2006) 2006 IPCC Guidelines for National Greenhouse Gas Inventories: Volume 4: Agriculture, Forestry and other Land Use. Intergovernmental Panel on Climate Change. Paris, France. http://www.ipcc-nggip.iges.or.jp/public/2006gl/vol4.htm.

Janzen HH, Desjardins RL, Asselin JMR, Grace B (1998) The health of our air: Toward sustainable agriculture in Canada. Agriculture and Agri-Food Canada, Ottawa, Ontario, p 98

Janzen HH, Beauchemin KA, Bruinsma Y, Campbell CA, Desjardins RL, Ellert BH, Smith EG (2003) The fate of nitrogen in agroecosystems: An illustration using Canadian estimates. Nutr Cycl Agroecosyst 67:85-102

Janzen HH, Angers DA, Boehm M (2006) A proposed approach to estimate and reduce net greenhouse gas emissions from whole farms. Can J Soil Sci 86:401-418

Khan DF, Peoples MB, Schwenke GD, Felton WL, Chen D, Herridge DF (2003) Effects of below-ground nitrogen on $\mathrm{N}$ balances of field-grown fababean, chickpea, and barley. Aust J Agric Res $54: 333-340$

Kirkegaard J, Christen O, Krupinsky J, Layzell D (2008) Break crop benefits in temperate wheat production. Field Crops Res 107:185-195

Kuwada K, Kuramoto M, Utamura M, Matsushita I, Ishii T (2006) Isolation and structural elucidation of a growth stimulant for arbuscular mycorrhizal fungus from Laminaria japonica Areschoug. J Appl Phycol 18:795-800

Laird D, Fleming P, Wang B, Karlen D (2009) Impact of biochar amendments on soil quality for a typical midwestern agricultural soil, Poster presentation. North American Biochar Conference, Boulder, Colorado, USA

Lal R (1995) The role of residues management in sustainable agricultural systems. J Sustain Agric 5:51-78

Lal R (2004) Carbon emission from farm operations. Environ Int 30:981-990

Leibovitch S, Migner P, Zhang F, Smith DL (2001) Evaluation of the effect of SoyaSignal technology on soybean yield [Glycine $\max (\mathrm{L}$.) Merr.] under field conditions over 6 years in eastern Canada and the northern United States, J. Agron. Crop Sci 187:281-292

Liang B.C., McConkey B.G., Campbell C.A., Johnston A.M., Moulin A.P. (2002) Short-term crop rotation and tillage effects on soil organic carbon on the Canadian prairies. An international symposium on agricultural practices and policies for carbon 
sequestration, Soil. Sci. Soc. Am. J., Special Publication, 287293.

Liang BC, Campbell CA, McConkey BG, Padbury G, Collas P (2005) An empirical model for estimating carbon sequestration on the Canadian prairies. Can J Soil Sci 85:549-556

Lynch JP (2007) Turner review no. 14. Roots of the second green revolution. Aust J Bot 55:493-512

Malhi SS, Grant CA, Johnston AM, Gill KS (2001) Nitrogen fertilization management for no-till cereal production in the Canadian Great Plains: A review. Soil Tillage Res 60:101-122

Marino D, Pucciariello C, Puppo A, Frendo P (2009) Chapter 5 The Redox State, a referee of the legume-rhizobia symbiotic game. Adv Bot Res 10:115-151

McConkey BG, Liang BC, Campbell CA, Curtin D, Moulin A, Brandt SA, Lafond GP (2003) Crop rotation and tillage impact on carbon sequestration in Canadian prairie soils. Soil Tillage Res 74:81-90

McGonigle TP, Miller MH (1993) Mycorrhizal development and phosphorus absorption in maize under conventional and reduced tillage. Soil Sci Soc Am J 57:1002-1006

Menalled FD, Gross KL, Hammond M (2001) Weed aboveground and seedbank community responses to agricultural management systems. Ecol Appl 11:1586-1601

Miller PR, Gan Y, McConkey BG, McDonald CL (2003) Pulse crops for the northern Great Plains: I. Grain productivity and residual effects on soil water and nitrogen. Agron J 95:972-979

Miransari M, Smith D (2009) Rhizobial lipo-chitooligosaccharides and Gibberellins enhance barley (Hordeum vulgare L.) seed germination. Biotechnol 8:270-275

Moot DJ, McNeil DL (1995) Yield components, harvest index and plant type in relation to yield differences in field pea genotypes. Euphytica 86:31-40

Paradis R, Dalpe Y, Charest C (1995) The combined effect of arbuscular mycorrhizas and short-term cold exposure on wheat. New Phytol 129:637-642

Peng S, Buresh RJ, Huang J, Zhong X, Zou Y, Yang J, Wang G, Liu Y, Hu R, Tang Q, Cui K, Zhang F, Dobermann A (2010) Improving nitrogen fertilization in rice by site-specific $\mathrm{N}$ management-A review, Agron Sustain Dev 30, 649-656. doi: 10.1051/agro/2010002.

Prasad R (2009) Efficient fertilizer use: The key to food security and better environment. J Trop Agric Food Sci 47:1-17

Rees WE (1992) Ecological footprints and appropriated carrying capacity: what urban economics leaves out, Environ. Urbanisation 4, 121-130, doi:10.1177/095624789200400212.

Reino JL, Guerrero RF, Hernández-Galán R, Collado IG (2008) Secondary metabolites from species of the biocontrol agent Trichoderma. Physiol Rev 7:89-123

Rochette P, Worth DE, Lemke RL, McConkey BG, Pennock DJ, Wagner-Riddle C, Desjardins RL (2008) Estimation of $\mathrm{N}_{2} \mathrm{O}$ emissions from agricultural soils in Canada. I. Development of a country-specific methodology. Can J Soil Sci 88:641-654

Rolfe BG (1988) Flavones and isoflavones as inducing substances of legume nodulation. Biofactors 1:3-10

Ruddiman WF (2003) The anthropogenic greenhouse era began thousands of years ago. Clim Change 61:261-293

Sawers RJH, Gebreselassie MN, Janos DP, Paszkowski U (2010) Characterizing variation in mycorrhiza effect among diverse plant varieties. Theor Appl Genet 120:1029-1039

Sieling K, Kage H (2010) Efficient N management using winter oilseed rape - A review, Agron. Sustain. Dev. 30, 271-279. doi: 10.1051/agro/2009036.

St-Arnaud M, Hamel C, Vimard B, Caron M, Fortin JA (1996) Enhanced hyphal growth and spore production of the arbuscular mycorrhizal fungus Glomus intraradices in an in vitro system in the absence of host roots. Mycol Res 100:328-332
Swift MJ, Vandermeer J, Ramakrishnan PS, Anderson JM, Ong CK, Hawkins BA (1996) Biodiversity and agroecosystem function. In: Mooney HA, Cushman JH, Medina E, Sala OE, Schulze ED (eds) Functional Roles in Biodiversity: A Global Perspective. John Wiley \& Sons, New York, pp 261-290

Unger PW (1978) Straw-mulch rate effect on soil water storage and sorghum yield. Soil Sci Soc Am J 42:486-491

Ussiri DAN, Lal R, Jarecki MK (2009) Nitrous oxide and methane emissions from long-term tillage under a continuous corn cropping system in Ohio. Soil Tillage Res 104:247-255

Van Loon LC (2007) Plant responses to plant growth-promoting rhizobacteria. Eur J Plant Pathol 119:243-254

Van Noordwijk M, Cadisch G (2002) Access and excess problems in plant nutrition. Plant Soil 247:25-40

VandenBygaart AJ, Gregorich EG, Angers DA (2003) Influence of agricultural management on soil organic carbon: A compendium and assessment of Canadian studies. Can J Soil Sci $83: 363-380$

Viscusi WK, Zeckhauser RJ (2006) The perception and valuation of risks of climate change: a rational and behavioral blend. Clim Change 77:151-177

Wackernagel M. (1994) Ecological footprint and appropriated carrying capacity: A tool for planning toward sustainability. (PhD thesis), Vancouver, Canada: School of Community and Regional Planning, The University of British Columbia. OCLC 41839429

Walley FL, Clayton GW, Miller PR, Carr PM, Lafond GP (2007) Nitrogen economy of pulse crop production in the Northern Great Plains. Agron J 99:1710-1718

West TO, Marland G (2002) A synthesis of carbon sequestration, carbon emissions, and net carbon flux in agriculture: comparing tillage practices in the United States. Agric Ecosyst Environ 9:217-232

Westerman PR, Liebman M, Menalled FD, Heggenstaller AH, Hartzler RG, Dixon PM (2005) Are many little hammers effective? Velvetleaf (Abutilon theophrasti) population dynamics in twoand four-year crop rotation systems. Weed Sci 53:382-392

Wiedmann T, Minx J (2008) A definition of 'carbon footprint'. In: Pertsova CC (ed) Ecological Economics Research Trends: Chapter 1. Nova, Hauppauge NY, USA, pp 1-11

Wiedmann T, Minx J, Barrett J, Wackernagel M (2006) Allocating ecological footprints to final consumption categories with inputoutput analysis. Ecol Econ 56:28-48

Yuan ZL, Zhang CL, Lin FC (2010) Role of diverse non-systemic fungal endophytes in plant performance and response to stress: progress and approaches, J. Plant Growth Regul 29:116-126

Zentner RP, Stumborg MA, Campbell CA (1989) Effect of crop rotations and fertilization on energy balance in typical production systems on the Canadian Prairies. Agric Ecosyst Environ $25: 217-232$

Zentner RP, McConkey BG, Stumborg MA, Campbell CA, Selles F (1998) Energy performance of conservation tillage management for spring wheat production in the Brown soil zone. Can J Plant Sci 78:553-563

Zentner RP, Lafond GP, Derksen DA, Nagy CN, Wall DD, May WE (2004) Effects of tillage method and crop rotation on nonrenewable energy use efficiency for a thin Black Chernozem in the Canadian Prairies. Soil Tillage Res 77:125-136

Zentner R.P., Brandt S.A., Nagy C.N., Frick B. (2009) Economics and energy use efficiency of alternative cropping strategies for the Dark Brown soil zone of Saskatchewan, Saskatchewan Agriculture Development Fund Final Report: Project 20070029. http:// www.agr.gov.sk.ca/apps/adf/adf_admin/reports/20070029.pdf

Zhang F, Smith DL (1997) Application of genistein to inoculate soil to overcome low spring soil temperature inhibition of soybean nodulation and nitrogen fixation. Plant Soil 192:141-151 